\title{
Monoclonal Protein Spike to Total Protein Ratio Measurement
}

National Cancer Institute

\section{Source}

National Cancer Institute. Monoclonal Protein Spike to Total Protein Ratio Measurement. NCI Thesaurus. Code C156508.

The determination of the ratio of monoclonal protein spike compared to total protein present in a sample. The measurement may be expressed as a ratio or percentage. 